\title{
Globalization and its impact on Slovak economy during corona crisis
}

\author{
Roman Hlawiczka ${ }^{1}$, Boris Kollar ${ }^{2, *}$ \\ ${ }^{1}$ University of Entrepreneurship and Law, Czech Republic \\ ${ }^{2}$ University of Zilina, Faculty of Operation and Economics of Transport and Communications, \\ Department of Economics Univerzitna 1,010 26 Zilina, Slovakia
}

\begin{abstract}
.
Research background: The presented article analysis major impacts of corona crisis on global and subsequently Slovak economy. It divides major impacts into several basic categories. These categories are presented in the methods part of the article. First of all, we analyze and discuss economic impacts, subsequently shocks in supply and demand and at last impacts of policies. These categories contain wide literature research in order to offer complex overview of the topic. The results and discussion part offers comparison of three important economic indicators. Namely gross domestic product, inflation rate and unemployment rate in periods before, during and shortly after the corona crisis. Some of the selected countries play major role in global economy - China, United States and European union. Other selected economies have the most direct impact on Slovak economy like Germany, Czech Republic, Hungary, Poland and Austria. For complex overview, we also included results of Euro area and Italy as a country with the worst course of pandemic.

Purpose of the article: Major purpose of presented article is description of major impacts of corona crisis on Global and Slovak economy. The need to shut down individual parts of economies and in some cases total lock down results in important damages. The article underlines these damages.

Methods: Among the methods used in this article, the most important one have descriptively analytical character. We also used other methods of formal logic like analysis, graphic method, comparison and synthesis.

Findings \& Value added: Overview of the major corona crisis impacts on Slovak and global economy during corona crisis.
\end{abstract}

Keywords: global economy, gross domestic product, unemployment rate, economic impact, globalization, economic policy

JEL Classification: $G 10 ; O 10 ; O 11 ; 115$

\footnotetext{
${ }^{*}$ Corresponding author: boris.kollar@,fpedas.uniza.sk
} 


\section{Introduction}

We often come across with the term globalization. To be able to better understand its meaning, it is important to define the concept of internationalization, which can be considered a specific phase of globalization. The whole concept of internationalization can be defined primarily as a process that takes place in several countries and includes processes such as the entry of companies into various foreign markets, the management of local subsidiaries, the management of international delegates and the management of crossborder business activities [1].

Internationalization in business is a multi-stage, complex process, the first step of which is to leave the familiar domestic environment. Such companies expand their operations first to the region, then to the continent and finally to the whole world. There are two forms of internationalization. The first is the evolutionary development that has been followed by many Western multinationals in Eastern Europe. Prior to the regime change, these organizations signed licensing and franchise agreements with companies in several countries in the region. The second form is a revolutionary development, in which many multinational companies bought companies after the opening of the Eastern market. Examples include the automotive industry Volkswagen-Škoda or Lenovo in the world of computers, which bought the IBM laptop store [2].

Some authors like Ellwood consider the term "globalization" to be one of the most frequently mentioned but least understood terms in the 21 st century [1].

Although globalization as a new concept has become fashionable only today, its beginnings date back a long time, as even then, there were different connections between different parts of the world. Humans and animals migrated through the spread of different techniques, cultures, plants, and the military and political societies of different countries became interdependent. Based on this, we can say that globalization is a process that is not just economic. Today, we can witness global problems that affect all of humanity and cannot be solved at the local level, and therefore require international cooperation. Undoubtedly, the most serious global problems of our time are overpopulation, nature pollution, depletion of the Earth's resources and also the danger of nuclear war [3].

In short, we can say that globalization is a process, not a finished fact, and that this process has important social, social, political and cultural aspects and effects [4].

In recent decades, the interpretation of globalization has been addressed by many authors and economists. This is evidenced by the US Library of Congress, which states that more than a thousand books have been published on globalization [5].

Wayne Ellwood argues that globalization is an old concept, as this process began in the 15 th century with the colonization of Europeans [1].

Globalization is a process that increases the dependence of markets and production of different countries due to the dynamics of trade in goods and services, the movement of capital and technology [6].

According to many economists, in the process of globalization, companies use resources (technology, capital, labor) available worldwide compared to their competitors. According to others, multinational companies are the engine of globalization nowadays. Many economists associate globalization with the activities of society, which is not surprising, because when we compare the activities of the 100 largest companies in the world, we see that the vast majority of companies have their headquarters outside of the United States. In addition to American companies, Japanese, French, German and English companies also play an important role in today's globalization [7].

This part of presented article deals with the overall economic costs may be divided into following three categories: direct costs, indirect costs, and long-term burden. 
Among the direct costs of Covid pandemic, we can include the extra spending on hospitals, staff, and medication, which are required to deal with a disease outbreak. These costs can understandably be quite significant. For example, the Ebola outbreak in 2015 cost around 5 billion euros in direct costs in Sierra Leone alone [8]. The estimates by the Global Health Risk Framework for the Future (GHRF) Commission state that infectious disease outbreaks cost the world around 50 bilion euros in direct costs annually on average [9]. It is important to realize that lost earnings of those who die during a disease outbreak are one of the main long-term burdens. For instance, Prager et alta have calculated that $80 \%$ of the economic losses in the case of a potential pandemic would be linked to the sum of expected future lifetime earnings of those who would die [10].

On the contrary, we underline that, this is not as much of the case for Covid pandemic, because it affects mainly older economically inactive people. However, it is the responsibility of whole society to protect this group of vulnerable citizens. Indirect costs are not insignificant neither, as they consist of all the elements leading to a GDP decline. Taking the SARS 2003 epidemic into account, we can see that despite its long-term and limited time span, it caused an annual GDP decrease of $1 \%$ in China and $0.5 \%$ in South Korea [11]. The income losses linked to the SARS outbreak in East and Southeast Asia were estimated to range between 10 - 25 billion of euros [12]. Beside of lower production and consumption losses, past pandemics have also partially affected the social order in some of the affected countries. For example, the Ebola pandemic in 2015 has shaken political stability in West Africa, disrupted important public services such as education, and transport and also reduced the quality of life for families and whole communities. They were often forced to be isolated [13].

\section{Methods}

Following part of presented article deals with impacts of Covid pandemic on economy. The are divided into four basic subcategories in order to better understand consequences as a whole.

\subsection{Economic impacts}

Major players in automotive industry completely suspended their production in numerous countries. Border closures, national quarantines, social distancing, and other measures made some operations harder to complete. The major concerns included transportation, entertainment, retail, and tourism sectors. Most professional sports leagues were suspended until further development and major sporting events like the Tokyo Olympic Games and UEFA Euro 2020 were postponed until 2021 for the first time in their history. The number of job losses in the United States has reached record highs unseen since the global economic crisis in 1930s. The world's economy is digitized and complex nowadays. Still, most economic processes require the proximity of individuals. This is however in direct contradiction with the health recommendations advised by World Health Organization. Even if the economic impacts are a secondary issue from the pandemic point of view, its consequences are substantial and may have longer impact on casual life.

International Monetary Fund's projections expect the 2020 global growth at $-3 \%$, a considerable decrease of over $6 \%$ projected in October 2019. This outcome is considerably worse than the one during the 2009 global financial crisis. The decline is expected to be $6.1 \%$ in the group of advanced economies, including the United States of America (-5.9\%), Japan (-5.2\%), the United Kingdom (- 6.5\%), Germany (-7.0\%), France (-7.2\%), Italy ($9.1 \%)$, and Spain $(-8.0 \%)$. In comparison, the emerging and developing economies are projected to decline by $-1.0 \%$ in 2020 . 


\subsection{Supply shocks}

The role and importance of China on the global trade have grown significantly in the past decades. The country has transformed its economy and is primary producer of high-value products and components, a large customer of global commodities and industrial products, and an attractive consumer marketplace nowadays. For example, Wuhan - the city where the pandemic started - plays an important part in many global supply chains. It plays major role in several industries like pharmaceuticals, bio-engineering, opto-electronic technology and modern manufacturing, such as automotive or steel and iron manufacturing. More than 200 of the Fortune Global 500 firms are also directly presented in Wuhan. Further, Wuhan and the Hubei province lockdown have affected the logistics within China. In response to the pandemic, the local authorities have prolonged Chinese New Year's holidays. Even after the end of the holidays, only about $70 \%$ of factories have reopened and at sub-optimal capacities.

Because we live in a globalized world, a supply shock in one local economy subsequently translates into a supply shock in other economies. Therefore, the decline of Chinese production is associated with a major decline of international trade flows. Chinese exports decreased by $17 \%$ between January and February, whilst the country's imports decreased by $4 \%$ in comparison to the same period of the 2019 . Such contractions are unprecedented, even if we compare it to the impacts of the 2003 SARS outbreak or the 2009 global financial crisis. These impacts have severe implications for producers and consumers around the world. It is important to understand, that $10 \%$ of all imported inputs into the German manufacturing sector have their origin in China, particularly in the electronics, computing, and textile manufacturing industries [14].

Decrease of international trade is caused by similar declines in production in the wide range of COVID-19-affected countries worldwide. The newly implemented procedures differ between each country. They have direct impact and complicate logistics of the international trade. The customs procedures, for example, have become rather cumbersome. Moreover, many countries have imposed large restrictions on trade with certain regions. These effects have had huge impact on the World Trade Organization's predictions. The worst-case scenario for the year 2020 predicts a decrease of $-31.9 \%$ in world merchandise trade due to the COVID-19 pandemic [15]. Another important part of the pandemic economic impacts is its burden on the supply of labour. First of all, infected labour force is not able to work for a substantial amount of time. This also affects healthy workers, because they have to be pull themselves out of their workplaces with the intent of not contracting the disease. Another problem is the need of many workers to stay at home with their children due to school closures. At the beginning of April, 188 countries closed their schools, which represented approximately 1.6 billion students ( $91 \%$ of all learners) being out of school [16]. For example, a survey of Chinese citizens conducted by Zhang et alta in late February discovered that $25 \%$ of the labour force had to stopped working, $38 \%$ worked from home, and only $27 \%$ continued working at an office [17].

\subsection{Demand shocks}

Several authors mention two aspects of demand shocks - practical and psychological. The practical aspects are quite logical, because consumers are likely to seek to reduce their risk of contracting the disease and decrease the demand for products and service which might involve close contact with other people $[18,19]$. As for the psychological demand shock, many of us still remember the last shock during the 2009 global financial crisis. The uncertainty about future economic developments led to both companies and individuals adopting the secure "wait and see" strategy. Many of them tended to postpone investments 
and purchases. This behaviour transformed the financial shock into a global demand shock. Although, the uncertainty of the current situation might be even higher. Kuc-Czarnecka suggest that the psychological aspect of the current demand shocks might have even bigger impact, because it might be unintentionally synchronized throughout the world by the international media and personal communication channels [17]. This synchronization might undermine the demand side of the global economy even further. The largest negative demand shocks are already being experienced by various industries. Among these industries there are the hospitality industry, the entertainment industry, and the travel industry. The decrease in demand further spills over to all other upstream and downstream sectors. For example, such decrease in the aviation industry is translated into lower demand for jet fuel. This is also one of the main reasons for the drastic fall of oil prices. To better understand this problem, the aviation industry is expected to incur 50 billion of euros losses due to the coronavirus-related demand decline, and an estimated 20 million of jobs in aviation industry are in danger [15]. The current demand shocks in the beforementioned industries were roughly predicted by the World Health Organization (WHO), which estimated that in case of a severe pandemic, the three worst-hit industries would be arts, recreation, accommodation or food services, transportation and warehousing industries [19].

\subsection{Government measures}

Governments around the world implemented policy measures in order to limit the health and economic impacts of the Covid pandemic. These measures were primarily oriented on containment limitation of the spread of the virus and they included restrictions on social gatherings, social-distancing measures, school closures, local and nation-wide lockdowns, and in many cases border closures. The biggest issue in connection to the pandemic is the high pressure it imposes on the national healthcare systems and the above-mentioned containment policies aid in slowing the spread of the virus. These policies are made to help hospitals and other medical facilities to deal with the burden. It is obvious that the implemented containment measures have significantly impacted the daily lives of people around the world and therefore the global economy as a whole. A large variety of businesses have become unable to operate due to governmental restrictions and also due to the coronavirus infection itself. Governments around the world imposed the measures to "freeze" the economy. These were imposed in order to faster recover after the end of pandemic. Specific sectors of the economy experience an especially acute fallout shock. Governments have to implement targeted fiscal, monetary, and financial market measures. This have to be done in order to help the most affected businesses and households [20].

\section{Results and discussion}

In the following chapter we will analyse, compare and summarize impact of corona crisis on three of the major economic indicators. In the Table 1, we can see summarized results of GDP growth in selected countries. Among the selected countries, there are three biggest economies in the world - China, United States and European Union. Other selected countries have direct impact on Slovak economy. These include Germany, Czech Republic, Poland, Hungary and Austria. For better overview and understanding of pandemic impact, we also present results of Euro area and Italy. Italy as one of the most affected countries experienced biggest downfall of almost $18 \%$. It is also interesting that Euro area has slightly worse results than European Union as a whole. The major role obviously plays the fact, that most affected countries with lockdowns were members of Euro area. From global 
point of view, it is evident that China was able to overcome the pandemic in the best condition from biggest economies.

Table 1. GDP growth in selected countries

\begin{tabular}{|c|c|c|c|c|c|c|c|c|c|c|}
\hline Country/Period & Q1-2018 & Q2-2018 & Q3-2018 & Q4-2018 & Q1-2019 & Q2-2019 & Q3-2019 & Q4-2019 & Q1-2020 & Q2-2020 \\
\hline European Union - 27 countries & $2,7 \%$ & $2,4 \%$ & $1,8 \%$ & $1,5 \%$ & $1,7 \%$ & $1,5 \%$ & $1,6 \%$ & $1,2 \%$ & $-2,7 \%$ & $-13,9 \%$ \\
\hline Euro are $\mathbf{-}-19$ countries & $2,5 \%$ & $2,2 \%$ & $1,5 \%$ & $1,1 \%$ & $1,5 \%$ & $1,2 \%$ & $1,4 \%$ & $1,0 \%$ & $-3,2 \%$ & $-14,7 \%$ \\
\hline Italy & $1,3 \%$ & $0,9 \%$ & $0,4 \%$ & $0,1 \%$ & $0,3 \%$ & $0,4 \%$ & $0,5 \%$ & $0,1 \%$ & $-5,6 \%$ & $-17,7 \%$ \\
\hline Czech republic & $4,8 \%$ & $2,6 \%$ & $2,7 \%$ & $2,6 \%$ & $2,4 \%$ & $2,4 \%$ & $2,3 \%$ & $2,0 \%$ & $-1,9 \%$ & $-11,0 \%$ \\
\hline Slovakia & $3,9 \%$ & $4,1 \%$ & $4,2 \%$ & $3,5 \%$ & $3,2 \%$ & $2,5 \%$ & $1,9 \%$ & $2,0 \%$ & $-3,8 \%$ & $-12,2 \%$ \\
\hline US A & $3,1 \%$ & $3,3 \%$ & $3,1 \%$ & $2,5 \%$ & $2,3 \%$ & $2,0 \%$ & $2,1 \%$ & $2,3 \%$ & $0,3 \%$ & $-9,0 \%$ \\
\hline China & $6,9 \%$ & $6,9 \%$ & $6,7 \%$ & $6,5 \%$ & $6,4 \%$ & $6,2 \%$ & $6,0 \%$ & $6,0 \%$ & $-6,8 \%$ & $3,2 \%$ \\
\hline
\end{tabular}

Following table 2 summarize the inflation rate and its development during first wave of corona crisis. It shows interesting development and difference between inflation rate Euro area and Czech Republic for instance. Inflation rate in Czech Republic speeded up in the last periods. The main reason is the monetary policy of Czech national bank, which decided to support its economy with the emission of bonds. The same development during corona crisis may be seen also in the case of China. On the contrary Euro area and United States have opposite development, despite the similar policy of European central bank and Federal reserve system.

Table 2. Inflation rate in selected countries

\begin{tabular}{|c|c|c|c|c|c|c|c|c|c|c|}
\hline Country/Period & Q1-2018 & Q2-2018 & Q3-2018 & Q4-2018 & Q1-2019 & Q2-2019 & Q3-2019 & Q4-2019 & Q1-2020 & Q2-2020 \\
\hline European Union - 27 countries & $1,3 \%$ & $1,8 \%$ & $2,2 \%$ & $1,9 \%$ & $1,5 \%$ & $1,6 \%$ & $1,2 \%$ & $1,3 \%$ & $1,5 \%$ & $0,6 \%$ \\
\hline Euro area - 19 countries & $1,3 \%$ & $1,7 \%$ & $2,1 \%$ & $1,9 \%$ & $1,4 \%$ & $1,4 \%$ & $1,0 \%$ & $1,0 \%$ & $1,1 \%$ & $0,2 \%$ \\
\hline Italy & $0,7 \%$ & $0,9 \%$ & $1,5 \%$ & $1,4 \%$ & $1,0 \%$ & $0,8 \%$ & $0,4 \%$ & $0,3 \%$ & $0,3 \%$ & $-0,1 \%$ \\
\hline Czech republic & $1,9 \%$ & $2,3 \%$ & $2,4 \%$ & $2,1 \%$ & $2,7 \%$ & $2,8 \%$ & $2,8 \%$ & $3,0 \%$ & $3,6 \%$ & $3,1 \%$ \\
\hline Hungary & $2,0 \%$ & $2,7 \%$ & $3,4 \%$ & $3,2 \%$ & $3,2 \%$ & $3,7 \%$ & $3,1 \%$ & $3,4 \%$ & $4,3 \%$ & $2,5 \%$ \\
\hline Slovakia & $2,3 \%$ & $2,8 \%$ & $2,7 \%$ & $2,2 \%$ & $2,4 \%$ & $2,5 \%$ & $2,9 \%$ & $2,9 \%$ & $2,8 \%$ & $1,9 \%$ \\
\hline USA & $2,2 \%$ & $2,7 \%$ & $2,6 \%$ & $2,2 \%$ & $1,6 \%$ & $1,8 \%$ & $1,8 \%$ & $2,0 \%$ & $2,1 \%$ & $0,4 \%$ \\
\hline China & $2,2 \%$ & $1,8 \%$ & $2,3 \%$ & $2,2 \%$ & $1,8 \%$ & $2,6 \%$ & $2,9 \%$ & $4,3 \%$ & $5,0 \%$ & $2,7 \%$ \\
\hline
\end{tabular}

The last table 3 represents development of unemployment rate in the selected countries. It is possible to notice, that governments tended to protect jobs in their respective countries. The exception is United States. Important factor in their growth is the law. Jobs are generally less protected in their labour system. China was able to overcome crisis with limited job losses. On the contrary Slovakia looks fragile and development of its labour market looks worse than in the nearby countries and also worse than in Germany and Euro area as a whole. Part of this result may be associated with the speed and accuracy of government's help, which was slower and less generous. Some sectors of economy in Slovakia have been underfinanced for long periods, such as agriculture and education [21]. This despite the fact, that they have long tradition in the country. 
Table 3. Unemployment rate in selected countries

\begin{tabular}{|c|c|c|c|c|c|c|c|c|c|c|}
\hline Country/Period & Q1-2018 & Q2-2018 & Q3-2018 & Q4-2018 & Q1-2019 & Q2-2019 & Q3-2019 & Q4-2019 & Q1-2020 & Q2-2020 \\
\hline European Union - 27 countries & $7,5 \%$ & $7,3 \%$ & $7,1 \%$ & $7,0 \%$ & $6,9 \%$ & $6,6 \%$ & $6,6 \%$ & $6,5 \%$ & $6,5 \%$ & $7,1 \%$ \\
\hline Euro area - 19 countries & $8,5 \%$ & $8,2 \%$ & $8,0 \%$ & $7,9 \%$ & $7,8 \%$ & $7,6 \%$ & $7,5 \%$ & $7,4 \%$ & $7,2 \%$ & $7,8 \%$ \\
\hline Germany & $3,5 \%$ & $3,4 \%$ & $3,4 \%$ & $3,3 \%$ & $3,2 \%$ & $3,0 \%$ & $3,1 \%$ & $3,3 \%$ & $3,8 \%$ & $4,3 \%$ \\
\hline Italy & $10,9 \%$ & $10,8 \%$ & $10,3 \%$ & $10,3 \%$ & $10,4 \%$ & $9,7 \%$ & $9,7 \%$ & $9,5 \%$ & $8,5 \%$ & $9,4 \%$ \\
\hline Czech republic & $3,5 \%$ & $2,9 \%$ & $3,0 \%$ & $3,1 \%$ & $3,0 \%$ & $2,6 \%$ & $2,7 \%$ & $2,9 \%$ & $3,0 \%$ & $3,7 \%$ \\
\hline Hungary & $3,9 \%$ & $3,6 \%$ & $3,8 \%$ & $3,6 \%$ & $3,6 \%$ & $3,3 \%$ & $3,5 \%$ & $3,3 \%$ & $3,7 \%$ & $4,6 \%$ \\
\hline Poland & $6,6 \%$ & $5,9 \%$ & $5,7 \%$ & $5,8 \%$ & $5,6 \%$ & $5,3 \%$ & $5,1 \%$ & $5,2 \%$ & $5,4 \%$ & $6,1 \%$ \\
\hline Slovakia & $5,6 \%$ & $5,4 \%$ & $5,4 \%$ & $5,0 \%$ & $5,0 \%$ & $5,0 \%$ & $5,0 \%$ & $4,9 \%$ & $5,2 \%$ & $7,4 \%$ \\
\hline USA & $4,0 \%$ & $4,0 \%$ & $3,7 \%$ & $3,9 \%$ & $3,8 \%$ & $3,7 \%$ & $3,5 \%$ & $3,5 \%$ & $4,4 \%$ & $11,1 \%$ \\
\hline China & $5,1 \%$ & $4,8 \%$ & $4,9 \%$ & $4,9 \%$ & $5,2 \%$ & $5,0 \%$ & $5,2 \%$ & $5,2 \%$ & $5,9 \%$ & $5,7 \%$ \\
\hline
\end{tabular}

The previous three tables summarized development before, during and shortly after the first wave of corona pandemic. Newer results were not available in the time of this article creation, but estimation expected slow recovery process. The biggest danger lies in the future development of pandemic and the success and availability of vaccine.

\section{Conclusion}

In the article we analysed, compared and summarized impact of corona crisis on three of the major economic indicators. Because the pandemic is still ongoing, it will be interesting to see these economic results after another waves and expected resurrection after the vaccine becomes available. Millions of individuals around the world have been contracted by the COVID-19 disease, and hundreds of thousands have died of it. Furthermore, additional hundreds of millions will probably suffer in the near future, because of the global economic recession provoked by the pandemic. This is the reason, why the study of potential consequences has primary importance. Even though the economic impact of the coronavirus pandemic is an extremely complex problematic with a wide range of connected factors, we tried to summarize the most important of them.

Despite limitation of this analysis, it is based mainly on short term data, we believe that it can serve as a point of reference in the future investigation of the issue. Once the data becomes available, additional research will need to be examined in order to understand the economics of the current pandemic as a whole. The analysis should contain the effects of policy measures on the duration of a recession and the speed and size of the subsequent recovery in individual countries.

The paper is an output of the science project VEGA 1/0210/19 Research of innovative attributes of quantitative and qualitative fundaments of the opportunistic earnings modelling which authors gratefully acknowledge.

\section{References}

1. Ellwood, W. (2003). Globalization. Budapest. HVG Kiadó Rt.

2. Poór, J. (2013). Internationalization and globalization in human resource management. Budapest. Complex Kiadó Jogi és Üzleti Tartalomszolgáltató Kft.

3. Szentes, T. (2005). Development, Competitiveness, Globalization. Budapest. Akadémia Kiadó.

4. Szentes, T. (2002). Globalization, regional Integrations and National Development in the World Economy of Our Time. Szombathely. Savaria University Press Alapítvány.

5. Beck, U. (2005). What is globalization. Szeged: Belvedere Meridionale Kiadó. 
6. Lyakina, M., Sheehy, S., Podhorska P. (2019). Networked and Integrated Urban Technologies in Internet of Things-enabled Smart Sustainable Cities. Geopolitics, History, and International Relations, 11(2), 62-68.

7. Poór, J. (2013). Internationalization and globalization in human resource management. Budapest: Complex Kiadó Jogi és Üzleti Tartalomszolgáltató Kft.

8. Gostin, L. O., Tomori, O., et al. (2016). Toward a Common Secure Future:Four Global Commissions in the Wake of Ebola. PLoS Medicine, 13(5), 1-15.

9. Maurice, J. (2016). Cost of protection against pandemics is small. The Lancet, 387(12), 1.

10. Prager, F., Wei, D., Rose, A. (2016). Total Economic Consequences of an Influenza Outbreak in the United States. Risk Analysis, 37(1), 4-19.

11. MacKellar, L. (2007). Pandemic influenza: a review. Population and Development Review, 33(3), 429-451.

12. Fan, E. X. (2003). SARS: economic impacts and implications. Asian Development Bank, 1-14.

13. Nabarro, D., Wannous, C. (2016). The Links Between Public and Ecosystem Health in Light of the Recent Ebola Outbreaks and Pandemic Emergence. EcoHealth, 13(2), 227-229.

14. Majercak, P., Kliestik, T., Masarova, G. et al. (2013). System Approach of Logistic Costs Optimization Solution in Supply Chain. Nase More, 60(5-6), 95-98.

15. Al-Ubaydli, O. (2020). Understanding How the Coronavirus Affects the Global Economy: A Guide for Non-Economists. Bahrain Center for Strategic, International and Energy Studies, 1-59.

16. Zhang, S. X., Wang, Y., Rauch, A. Wei, F. (2020). Health, distress and life satisfaction of people in china one month into the covid-19 outbreak. Psychiatry Research, 288, 119.

17. Kuc-Czarnecka, M. (2020). COVID-19 and digital deprivation in Poland. Oeconomia Copernicana, 11(3), 415-431.

18. Majercak, P., Majercakova, E., Nedeliakova, E. (2014). Management of Optimization in Logistics Leads to Savings in Transport Costs. In 18th International Conference on Transport Means (pp. 364-367). Kaunas: Lithuania.

19. Korzeb, Z., Niedziółka, P. (2020). Resistance of commercial banks to the crisis caused by the COVID-19 pandemic: the case of Poland. Equilibrium. Quarterly Journal of Economics and Economic Policy, 15(2), 205-234.

20. IMF (2020). The Great Lockdown. World Economic Outlook. Retrieved from: https://blogs.imf.org/

21. Valaskova, K., Durana, P., Adamko, P., Jaros, J. (2020). Financial Compass for Slovak Enterprises: Modeling Economic Stability of Agricultural Entities. Journal of Risk and Financial Management, 13(5), 92. 